\title{
環境变化に対応した農業経営戦略に関する一考察
}

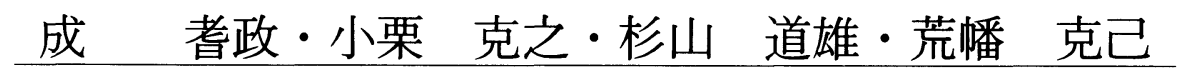

\section{Farm Management Strategy in Response of the Environmental Changes}

\author{
Kijung Sung, Katsuyuki Oguri, Michio Sugiyama and Katsumi Arahata
}

(Gifu University)

Today, farm management is placed under severe management environment changes. The environmental condition for farm management depends on internal and eternal factors which diversify with elapse of time. In farm management, to always achieve management growth in production, it is necessary and indispenable for proper correspondence between inside and the outside environmental changes. The execution of effective managemental strategies are demanded for successful growth in the future.

Therefore, in this paper, it is discussed and analysed whether or not the farm management which is placed in under severe management environmental changes and the farm strategy in order to overcome the problems. In this case, it puts the management strategy theory of the general management which is precedent as approach in the eyesight and considers it.

\section{1.はじめに}

今日, 農業経営は極めて䈗しい経営環境変化の下に おかれている. そして, 農業経営が直面している経営 内部の環境条件は個々の経営によってそれぞれ異な り, また，経営外部の環境条件も時間の経過とともに 多様化していく．農業経営が経営成長を常に成しとげ ていくためには，このよらな経営の内部扰よび外部環 境变化に適切な対応を行っていくことが必要不可欠な ことである. そのために有効な経営戦略の策定と実行 が求められる.

そこで本稿では, 今日のような厳しい経営環境の中 におかれている農業経営が環境変化に対応して，どの よらな戦略を構筑していくべきかを明らかにすること を課題にした．その場合，アプローチの方法として先 行している一般経営学の経営戦略論を視野に入れて考 察する.

以下，第 2 節においては経営戦略論の基本的な概念 および農業経営における経営戦略論の先行研究を概観 し, 概念的フレームワークを明らかにする. 第 3 節で は農業経営を取り巻く経営環境を分析し, 経営戦略の 構筑の基礎を設定する. 第 4 節では環境变化に対応し た農業経営の経営戦略の構築およびその検証を採卵鶏
経営の分析で試みる．最後に第 5 節ではむすびとして 小論のまとめと今後の課題について述べる.

\section{2. 概念的フレームワーク}

\section{（1）経営戦略論の定義}

経営戦略といら用語は経営戦略論におけるキーワー ドであるが，論者によって異なった意味合いで用いら れている。 また，一般経営学に批る経営戦略の内容 および体系のとらえ方もいくつかみいだされてい $ろ^{1)}$.

経営戦略とは，「(経営) 環境変化に積極的に適応 し, 対処していくために, 状況把握, 目標設定, 行動 代替案の探索とデザイン, 代替案の評価選択とい5 4 つのステップで形成される行動計画あるいは政策であ る」2)，といわれる。この定義のポイントは環境变化に 適応し, 対応するといら経営戦略の 1 つの目的を明確 に示唆した点である。また，経営戦略の構築プロセス を状況把握（経営環境分析） $\rightarrow$ 目標設定 $\rightarrow$ 行動代替案 の探索とデザイン（戦略の作成）－代替案の評価と修 正のよらなステップで明示した点である。つまり経営 戦略とは, 環境変化の影響に対応し, 経営成長を成し とげていくための政策手段であるといえる. 


\section{（2）農業経営における経営戦略論}

\section{一先行研究のレビュー一}

戦略といら言葉が経営に関わる分野で普通に使われ るようになったのは1980年代に入ってからであると言 われる.これまで農業経営分野でも経営戦略論に関す る議論が行われてきたが, 主に経営計画論, 農業経営 政策論, または与件変革論の形での議論であった ${ }^{3)}$.

ここでは, 最近, 活発に行われている農業経営戦略 に関する議論について論者別（木村伸男，大泉一貫， 新山陽子の 3 氏）にまとめてみることにする.

木村伸男氏4) は, 農業の経営を改善していくために は農業経営者がビジョン（どらありたいか）を持つこ とが重要だと前提して，このビジョンを可能にするた めに「何をなすべきか」といら戦略を考刍なければな らないといら。また，こらした戦略を日常の中で戦術 といら形で実施し経営改善を行らことが重要であると い5.

より具体的には「戦略とは, 経営者が, 長期的に発 展していくための将来方向・基本目標を決め, それを 実現していくための指針である」と定義し, 農業経営 戦略に拈ける経営内部の長期成長戦略の構築を強調し ている.

大泉一貫氏5) は, 農業経営のビジョンといら視点か ら発展段階を区分する．その第1 ステージは「生活す るための農業」である。この段階では「生業」であっ て「経営」にはなっていない，第 2 ステージは「他人 の力を借りる農業」である。儲かる農業を実現するた めには「他人の力を借りる農業」に転換する必要があ るという．第 3 ステージは「他人のためになる農業」 である.この段階で経営者は「地域の中で自分自身の 経営の客観化」がはじまる. 最終ステージは「社会の ためになる農業」を目指すことである。これまでの経 営の発展過程は「私的な経済的目標」から，より「社 会的な目標への転換」を意味し，農業経営が「社会性 を得る過程」といってよい。つまりここでは「社会 的な意味づけが重要」であるという.

新山陽子氏6) は, 企業的展開がもっとも進んでいる 畜産分野を対象に，経営発展の条件とそれをもたらす 経営戦略の内容を分析している. 畜産経営の発展段階 を「生産規模拡大」 $\rightarrow$ 「企業形態の転換」 $\rightarrow$ 「事業の 多角化・企業グループ化」の 3 段階に区分して段階別 に経営転換の具体的内容をあげている，また，畜産に おケる経営戦略の重点は「経営の内部構造を变革」す ることによってなされる「経営基盤の形成」にあると して, 畜産の経営戦略の体系を「基本戦略」と「個別
戦略」に分けて，後者はさらに「対外的戦略」と「内 部体制形成戦略」から構成されるとしている. そして 畜産経営の発展ステージごとに基本戦略と個別戦略を 示している.

以上のことから分かるよらに木村・大泉・新山の農 業経営戦略論は, 具体的な経営実践から発展段階別の 経営戦略を提示している．また，以上みてきた農業経 営戦略論は農業経営の経営成長ステージ論的な立場か ら構筑した農業経営内部の長期戦略といえる。これに 対して本稿では環境变化に積極的に対応していくとい ら視点からの農業経営の短期戦略の構築を試みる.

\section{3. 農業経営環境の分析}

農業経営の環境対応のプロセスを分析するに当たっ て，まず「環境とは何か」について考察しなければな らない。「環境とは, システムの外部にあってその属 性の变化がシステムに影響を与え, その属性がシステ ムによって影響を受けるよらな事物のすべての集合で ある」7) と定義する。経営環境といらと, 経営を取り 巻くものすべてと考党がちであるが，経営環境は経営 を取り巻くもののなかで, 経営が活動するに当たっ て，何らかの影響を及ぼするのに限定する。つまり， 経営環境は, 経営の主体である経営者, その機能の現 れとしての経営行動に影響を及洔す条件を集合したも のといえる.

また，経営が対応しなければならない環境は大きく 次の 3 つに分類できる．第 1 に，社会環境は社会一 般, 文化・歴史, 自然, 教育, 法律, 政治, 経済とい った諸要素からなるマク口的な環境である。第 2 に， タスク (課業) 環境は経営組織の事業活動に直接関係 寸る環境であり, 供給業者, 流通業者, 消費者, 競争 者, 地域社会といった諸要素から構成される。さら に, 第 3 に, 組織環境は理念・目標, 経営資源, テク ノロジー，組織風土といった組織を規定する諸要素か ら構成される環境である。社会環境及びタスク環境 は，経営の外部にあってその活動に影響を及ぼすとい ら意味で外部環境であるといえるのに対し, 組織環境 は, 経営組織内部にあって環境と組織を媒介する諸要 素から構成され, 組織内の意志決定主体にとっての環 境といら意味で内部環境といえる.

経営戦略の全過程において，環境分析，とくに外部 環境分析の果たす役割は，極めて重要である。それ は, 外部環境の変化への対応を誤ると, 経営を破隇へ の道に追いやることになりかねないからである。すな わち, 環境分析の目的は, 経営体にとって環境变化の 
要因が，将来の経営構造に与える影響度を明確にする ことである．また，経営環境の変化の動向の中から新 しい事業展開の機会を見出すことである．外部環境の 变化要因の的確な分析・把握とそれに対応する経営戦 略の構築は, 経営戦略全体のプロセスの中核をなする のである.

\section{（1）環境分析モデルの類型}

環境分析の接近方法として次の 3 つのモデルが開発 されている8)。第 1 に，不規則的モデルである。これ は一般に使用される頻度がもっとも高いが，主として 緊急避難的対応を基盤とするもので, 環境に抢ける予 期せざる出来事や危機の発生に焦点が合わされる.し たがって, 適応型アプローチの典型であり, 農業経営 環境変化に対応して行われる意志決定も現在およびき わめて近い未来だけを念頭においいたものとなる.

第 2 K，周期的モデルは，定期的に実施され，意志 決定に関わるまたは問題志向的な環境の再吟味であ り, このモデルも現在から近い未来のトレンドに焦点 が当てられる.

第 3 に, 継続的モデルである.このモデルは意志決 定への情報提供に加えて, 戦略機会や問題点の発見を 志向する. これは前述の 2 つのモデルに比べて事前対 応的でプロセス志向をとる.

（2）農業経営における主な外部環境の変化

経営戦略とは経営を取り巻く外部環境変化 ${ }^{9}$ に対応 できる政策を施すことでもあると述べてきた。ここで は農業経営を取り巻く主な外部環境の变化として, 農 産物市場の变化, 農業労働市場の变化と土地市場变化 について概略を述べたい，

まず，アウトプットに関する経営環境である農産物 市場の変化である.この農産物市場变化の主な要因と して消費者ニーズの变化と輸入農産物の増大が挙げら れる. 経営戦略の 1 つは「消費者志向に即した経営活 動」といらことであろう．この消費者志向に即した経 営活動とは，「消費者のニーズを発見し，それに応じ た製品を開発し，それを適正なコストで生産し，消費 者に届けることを重視する個人や組織の活動」10) であ る. したがって, 多様化, 高品質化と安全性志向等の 需要の質的变化に対応し，消費者ニーズに応じた農産 物を生産・販売しなくてはならないまた，輸入自由 化によって海外農産物が大量に導入され，国内農産物 は外国産農産物との激しい市場競争にさらされてい る.

第 2 亿, 農業労働市場の変化が挙げられる. 他産業 の発展から農村・農家出身者の職業選択の幅が広が
り, 農工間の所得格差から農業労働力が他産業に大量 に流出し, 農村では農業労働力の減少・高龄化, そし て農家そのものも減少しつつある.

第 3 に, インプットに関する経営環境である生産要 素市場（土地，資材等）の変化，特に，ここでは土地 市場条件の変化について述べたい，農地市場の動 向11)，つまりどのような農地移動がどれほど発生して いるのかをみよう．1985年から93年の農地移動の動向 をみると，利用権等の設定件数は停滞しているが，移 動面積は增加する方向にある。また，有償移動は大き く減少し, 移動面積も減少している. そして不耕作地 や耕作放棄地子増加しつつある。

（3）農業経営における主な内部環境の変化

戦略とは「外部環境変化に対応できる内部環境を作 り上げること」12) でもある．一般経営学では経営の内 部環境を経営文化・風土といら側面と経営資源の要素 からとらえている.ここでは経営資源の諸要素といら 側面からとらえる.すなわち，(1)人的資源の側面とし ては従業員の年龄別構成, 人件費の水準, 就労時間, 就労条件等があり，(2)資金側面では，財務構造，資金 の調達力等, そして(3)物的資源の側面からみると, 生 産形態及び販売形態, 施設, 設備水準等が挙げられ る.ささらに(4)経営情報の側面 ${ }^{13)}$ からみると, 農業経営 で利用されている経営情報システムやインターネット による農業経営情報の収集, CATV, FAX, PC 等に よる「地域農業情報ネットワーク」14) の形式等があ る.

\section{4．環境変化に対応した農業経営戦略の構築}

\section{(1) 対応戦略の構築}

農業経営が対応戦略を構筑するに当たって重要な一 つは, 経営環境が重視されるとはいえ, 経営がこの環 境に一方的に規定される存在ではない，必要であれ ば，経営側から環境唓きかけて，経営にとって望ま しい内部経営環境につくりかえることもある程度可能 であろら。

対応戦略とは, 環境変化への反応を意味し, 事後的 対応と事前的対応の双方の戦略が含まれる. 事後的戦 略とは，しばしば危機的状況下での環境の大きな変化 に対する対応としての性格が強く, 事前的戦略とは卜 レンドの発生を見越した先行型戦略である.

M.E. Porter ${ }^{15)}$ によれば，競争上の優位を獲得する ための基本戦略は次に 3 つあるとい5．第 1 に，コス トリーダーシップ戦略である。これはコスト面で最優 位に立つといら基本目的にそった一連の実務政策を実 
行することで, コストのリーダーシップをとろらとい ら戦略である。

第 2 に，差別化戦略である．自社の製品やサービス を差別化して，業界の中でも特異だとみられる何かを 創造しようとする戦略である。つまり, 独自の製品や ブランドの商品を作ることによって，自己経営にとっ て独自の市場を形成しようとする戦略である.

第 3 に, 集中戦略である. 特定の買い手グループと か, 製品の種類とか, 特定の地域市場とかへ, 企業の 資源を集中する戦略である。この戦略は低コスト戦略 と差別化戦略とは違って, そもとも特定のターゲット だけを扱ら目的で策定されるものである。たとえば， 特定野菜などの産地化をはかることによって，特定市 場における一定時期だけの市場占有率を高める方向へ の取り組みや，有機栽培によって特定消費者グループ のみを対象とした農産物を販売する取り組みなどであ る.

また，佐々木氏 ${ }^{16)}$ は環境変化汇対する農業経営の対 応方法として, 対応方法の相違といら視点から, (1)現 状延長戦略, (2) 状況反応戦略, (3)状況対応戦略, そL て(4)変革戦略に分けて各々の対応方法の特徵を整理し ている.

次に，八木俊輔氏17) は， R.E. Miles \& C.C. Snow の研究成果を踏まえて「経営戦略の相違」といら点か ら農業経営に対する対応パターンを，「(1)安定志向型 (経営戦略は既存追求型), (2)変革志向型（経営戦略 は新品目探索・導入型), (3)バランス型 (1)と(2)の折 哀型, すなわち, 経営基盤は既存の品目におくが, 新 品目の導入可能性を常に探求する経営戦略), (4)受身 型 (経営戦略は未確立)」の 4 つに類型化している. また同氏はこれれらの対応パターン類型は「いずれも 経営環境に意図的・効果的に対応していることを示し ていることであって，優劣をあらわすものではない」 と強調している.

前節で述べた農業経営の内部及び外部環境要因の分 析と, 先行研究の成果 (ポーター, 佐々木, 八木の 3 氏）を踏をえて，農業経営を取り巻く外部環境变化に 対する対応方法を経営の柱である作目变換の有無を中 心に類型化すると次のようになる. 第 1 に, 変換型戦 略（組織変革型）である。この戦略は常に経営の収益 性向上を追求して作目構成の变換を行う. 経営管理や 経営組織も作目構成の変換に対応しやすいよらに作り 上げる.

第 2 K，対抗型戦略（コスト低下型）である。これ は, 作目の変換はせず既存の同一作目で新しい栽培技
術の開発などによって生産効率を上げ，コスト低下を 図って外部環境变化（農産物の輸入等による市場価格 の低下等）に対抗する戦略である．この戦略では独自 の栽培技術開発のための施設を整備したり, 生産設備 に巨額の投資を行ったりする必要がある.

第 3 に, 攻撃型戦略（差別化型）である.これは, 作目の変換はせず既存の同一作目で差別化を図ってい く戦略であり, 農業経営の競争的地位を高めることを 狙って環境変化につけいる戦略である。つまり, 同種 の作目に対する消費者の新しい意向をいち早くつか み，製品やサービスの差別化を行うことによって他製 品よりも高い価格で消費者から買ってもららといら戦 略である，たとえば，果樹，米，卵などの特定品種銘 柄の生産・販売, 産地銘柄の形成などである。また， 市場のシェアが小さい農業経営がリーダー経営や競合 経営に攻撃をしかけ市場シェアの拡大を図る市場チャ レンジャ一の競争戦略も含む. 具体的には, 既存の農 産物で満たされていない市場の腙間を探し，その二ズを満たし，強力なセグメントに成長させる戦略もそ の一つである.

\section{（2）農業経営戦略構築の実態分析} 一有限会社 A 経営の事例分析一

この事例の実態分析では, 農業経営の外部環境変化 の対応方法として構築した 3 つの対応戦略のらち, 一 例として攻撃型戦略（差別化型）を取り上げ，その検 証として採卵舀経営のブランド化戦略に焦点を置いて 分析を行らことにする。これは採卵舀経営が持つ特 徵, 特に事例の上らな小規模の経営は差別化による攻 撃型戦略が最も有効であると考号られるからである.

1) 経営の概況

$\mathrm{A}$ 経営の経営概要は表 1 亿示したが, 平成 5 年度に 有限会社として設立された静岡県中部の広域市圏に位

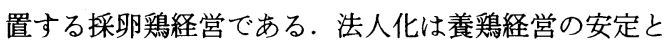
取引の社会的信用性を目的に行い, 構成員は経営主 1 人で，出資金は 300 万円である．労働力としては経営 主と妻, 父の 3 名のほかに雇用者（パート）が 3 名い る、A経営の主な事業内容としては採卵鷄の飼着管理 と舀卵販売である.

2）経営の展開過程

表 2 亿A経営の展開過程を示したが, 養鷄経営は昭 和 20 年に父が自宅の隣接地において開始した。昭和 44 年には県道拡幅に伴い現在地に移転し，3,000羽飼盖 の経営となる. 昭和56年の 25 才の時に就農したが，就 農までは県立高校卒業後, 地元の木工家具メーカーに 就職し，製造・設計に携わっていた。就農から 4 年 
表 1 . A 経営の労働力の構成

\begin{tabular}{|c|c|c|c|c|}
\hline 区 分 & 続 柄 & 年 龄 & 作業日数 & 作業の 分担 \\
\hline 家 族 & $\begin{array}{l}\text { 本人 } \\
\text { 妻 } \\
\text { 父 }\end{array}$ & $\begin{array}{l}39 才 \\
37 \\
69\end{array}$ & $\begin{array}{l}310 \text { 日 } \\
310 \\
310\end{array}$ & $\begin{array}{l}\text { 飼養・経営管理・販売 } \\
\text { 飼養・販売管理・ネット詰め } \\
\text { 配合飼料調合・衛生管理 }\end{array}$ \\
\hline 雇 & $\begin{array}{l}\text { 義 } \\
\text { パート } \\
\text { パート }\end{array}$ & 61 & $\begin{array}{l}252 \\
313 \\
313\end{array}$ & $\begin{array}{l}\text { 直売所の管理・ネット詰め } \\
\text { 集溜・鶏の移動・仕分け等の作業 } \\
\text { 衛生管理・ネット詰め・パック詰め等 }\end{array}$ \\
\hline 合 計 & 6名 & & 1,808 日 & \\
\hline
\end{tabular}

表 2.A経営の経営展開過程

\begin{tabular}{|c|c|c|}
\hline 昭56 & 採卵経営開始, $1,150 \mathrm{~m}^{2}$ の土地を取得, 規模払大の足掛かりとする & $\langle 6,000$ 羽 $\rangle$ \\
\hline 57 & No 4, 5 鶏舎の増築, $607 \mathrm{~m}^{2}$ の取得 & \\
\hline 58 & No 4 鵎舎を更に増築, $370 \mathrm{~m}^{2}$ の取得 & $\langle 6,800$ 羽 $\rangle$ \\
\hline 59 & No 6 䊿舎の増築（近代化資金)，自動販売機設置 & $\langle 9,200$ 羽〉 \\
\hline 60 & 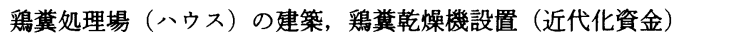 & \\
\hline 61 & No 5 半分増築，青色申告の開始 & $\langle 10,400$ 羽 $\rangle$ \\
\hline 62 & No 1 大䧽舎の半分増築（近代化資金） & \\
\hline 63 & 育成舎の増筑（近代化資金), 卵価暴落による経営悪化一赤字経営 & \\
\hline 平元 & ブランド卵の開発・販売開始，一般卵より1パック40円高で取引 & \\
\hline 2 & 飼料倉庫の建築（近代化資金） & \\
\hline 3 & 鶏舎の増築 (近代化資金), 洗卵選別機の導入, トラック 1 台購入 & $\langle 12,000$ 羽 $\rangle$ \\
\hline 4 & 鷂舎の増築 (近代化資金), 給水システムの導入, 自動販売機設置 & $\langle 15,000$ 羽 $\rangle$ \\
\hline 5 & 有限会社の設立, 自宅に販売所の新築 & \\
\hline 6 & 直売所の駐車場整備，パソコン導入 & \\
\hline 7 & ブランド卵の販売マニュアル作成 & \\
\hline 8 & ラン (卵) ネットワークの開始, 移転計画の樹立 & \\
\hline
\end{tabular}

資料 : 表 1 と同じ

後，成鷄舎を増改築して飼養羽数を 12,000 羽とし，昭 和61年に父から経営移譲された。 しかし，昭和63年に は卵価が大暴落し, 経営は悪化した。

そこで平成元年には，自家飼料配合によるブランド 卵を開発した。その上で生産のみならず販売を重視 し，独自ブランド贸の直接眅売を進めた. 地元のスー パーマーケットとの取引を行うよらになり, 経営安定 と社会的信用の確保を目的に平成 5 年度には経営を法 人化し，有限会社を設立するに至った．

3）経営戦略構築の実態と経営活動の特徵

農業経営戦略とは，前述したように農業経営を取り 巻く環境の変化に積極的に対応していくための政策手 段であるとい方る.A経営では昭和63年の卵価暴落に よる経営覀化といら外部環境の変化に敏速に対応し て, 差別化商品の形成による経営の立て直しを図っ た。ここではA経営が厳しく变動する農業経営環境の 中で経営目的を達成していくための戦略的経営管理の 内容を, その経営ビショョン, 経営戦略と経営戦術に分 けて整理してみることにする（表 3 ).
まず，A経営の経営ビジョンは「都市生活者に対し て安心できる農産物を提供し, 農業・農村の大切さを 理解してもらえる経営の確立」である。そして経営戦 略としては「独自ブランド卵の販売により企業利潤の 増大を目指す効率的な採卵䳕経営体の確立」である. この経営戦略を達成するための具体的な経営管理行動 として現れる経営戦術は,「独自ブランド卵の開発・ 販売」,「パソコンによる経営管理体制の確立」「ネッ トワークづくりによる経営情報交換」, そして「地域 の環境保全への取り組み」などが挙げられる。これら について少し具体的に述べると, 第 1 亿, 独自ブラン ド卯の開発と販売への取り組み18)である．A経営で は，採卵鷄経営を取り巻いている経営環境の变化に積 極的に対応するために飼料原料の研究を行って独自の 卵であるブランド卵の開発に成功した．その独自のブ ランド卵とは，健康な鵎から高品質の卵が生をれるこ とを基本とし，天然素材を使用した自家配合飼料の研 究を重齐て開発した「美しい卵，美味しい卵」である。 手作りのエサには，一般飼料にはほとんど含まれて 
表 3.A経営の経営ビジョン, 経営戦略と戦術

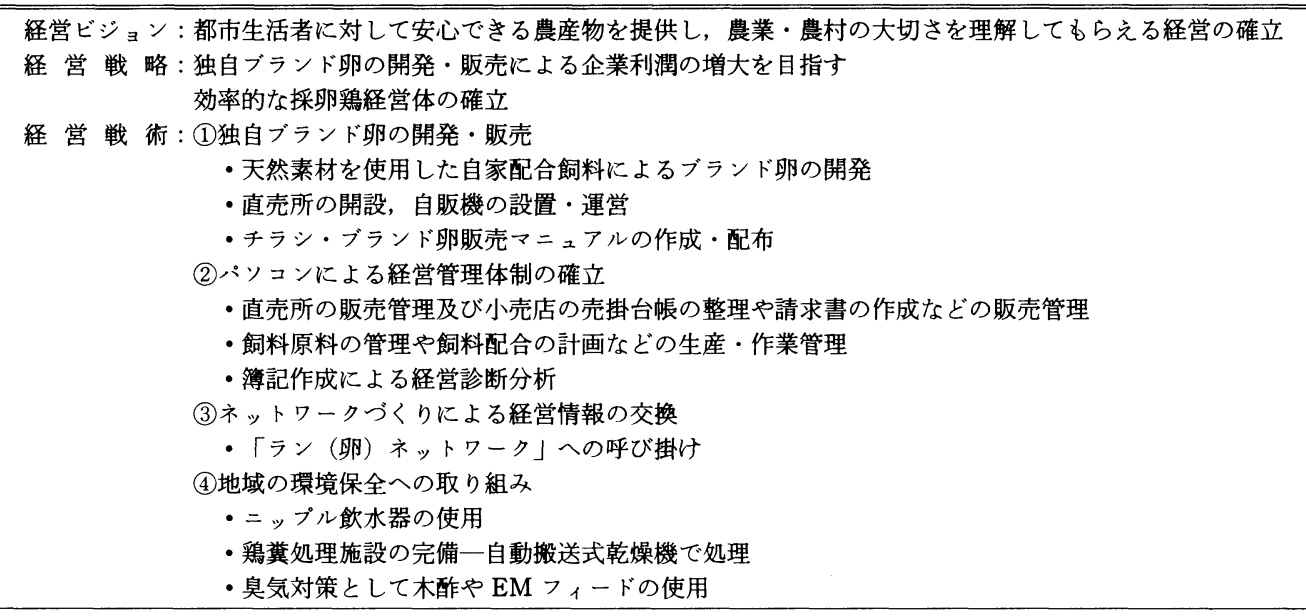

資料：表 1 と同じ

いないにんにく，とらがらし，マンノースオリゴ糖，

乳酸菌, 天然アミノ酸, 海藻, 乾燥青菜などを使用 し, 抗生物質, 薬品等は一切使用していない。缸 の飲水には磁気処理イオン水を使い，飼料には胃や腸 での消化吸収を高める活性微生物とオリゴ糖を配合 し，鷄の健康管理にも努めている。

販売面では, 直売所での販売卵の確保のために, 年 間の導入回数を増やし更新率を高め, 卵のサイズ・産 卵量の安定化を図り, 取引先への納入計画を立てて,
販売の安定を図っている。またスーパーマーケット との取引の増加のため「ブランド卵販売マニュア ル」19）を作成し，店頭に揭げるポップやチラシなどで 販売店や消費者の要望にも積極的に対応している。

第 2 K，パソコンによる経営管理体制の確立が挙げ られる. 経営管理にパソコンを用い, 直売所の販売管 理および小売店の売り掛け台帳の整理や請求書の作成 を行っており，飼料原料の管理や飼料配合計画，ワク チンプログラムなどの生産管理・作業管理にもパソコ

表 4. $\mathrm{A}$ 経営の戦略的経営管理の内容一改善前の問題点と取り組み内容

\begin{tabular}{|c|c|}
\hline 改善前の問題点 & 戦略的経営管理の取り組みと改善内容 \\
\hline $\begin{array}{l}\text { *手作業による規格選別のた } \\
\text { め, 販売価格にロスがあっ } \\
\text { た. }\end{array}$ & $\begin{array}{l}\text { ・規格選別機を導入し，正規な規格選別と取引価格の妥当性に努めた．規格の統一性を図った. } \\
\text { ・機械化によっでートでも容易に作業ができ，労働面での改善ができた. }\end{array}$ \\
\hline $\begin{array}{l}\text { ＊鷄卵生産量が不安定であっ } \\
\text { た. }\end{array}$ & $\begin{array}{l}\text { ・卵のサイズ，産卵量の安定化を図るため，年間の觹の導入回数を增やしたり，良質卵の増加の } \\
\text { ため更新率を高めた. } \\
\text { ・取引先の納入計画を立て直売所の確保に努める. }\end{array}$ \\
\hline $\begin{array}{l}\text { ＊養舀場直送卵のメリットが } \\
\text { なかった. }\end{array}$ & $\begin{array}{l}\text { ・養鶏場直送卵と問屋経由卵との価格差がなく，新鮮で安心される鵎卵の開発に手掛けた. } \\
\text { ・ブランド卵の開発と共に飼料等の研究を行い，独自卵を開発し完成した. }\end{array}$ \\
\hline $\begin{array}{l}\text { * 消費者が湌鵎場直送卵を知 } \\
\text { らなかった. }\end{array}$ & 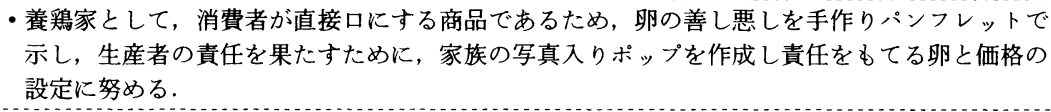 \\
\hline $\begin{array}{l}\text { *取引先担当者が鵎卵生産の } \\
\text { 実態が判っていなかった }\end{array}$ & $\begin{array}{l}\text { ・担当者の卿に対する認識を深めるため, ブランド卿の販売マニュアルを作成したり, 責鷄場の } \\
\text { 視察研修等積極的に取り組んだ. }\end{array}$ \\
\hline $\begin{array}{l}\text { * 作業分担・労働力の確保が } \\
\text { 困難であった. }\end{array}$ & $\begin{array}{l}\text { ・法人化への移行により, 社会的信用の確立が図られ，パート雇用の安定確保（社会・労働保険 } \\
\text { 等の加入）や家族に対す給与制の確立と節税対策につながった. }\end{array}$ \\
\hline $\begin{array}{l}\text { * 経営管理の係数整理が繁雑 } \\
\text { であった. }\end{array}$ & $\begin{array}{l}\text { ・パソコンの導入によって，小売・直売所等の販売管理や生産管理による技術管理，また飼料設 } \\
\text { 計・ワクチネーションプログラム等の実施計画の作成を行っている. }\end{array}$ \\
\hline $\begin{array}{l}\text { * 経営収支と経営戦略の確立 } \\
\text { が困難であった. }\end{array}$ & $\begin{array}{l}\text { ・改善前の経営収支は, 卵価の低迷等もあって非常に厳しい状況であったが，経営戦略ブランド } \\
\text { 卵の確立によって，経営の安定が図られた。 }\end{array}$ \\
\hline
\end{tabular}

資料: 表 1 と同じ 


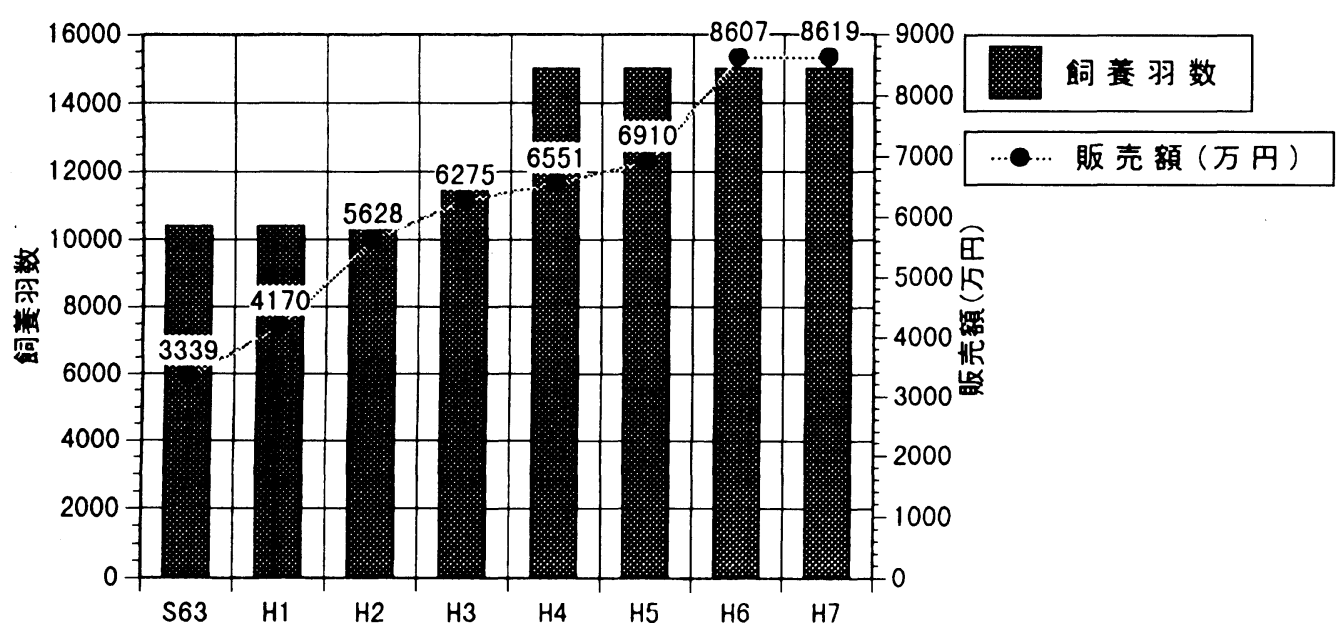

図 1.A経営の飼養羽数と販売額の推移

ンを用い，個別の経理を行って年度比較や生産計画に 活かしている.

また，小売店の店頭に揭げるポップや販売マニュア ル，消費者向けのチラシなどもパソコンを使って作成 （カラーのイラストや図表, 写真等を挿入）してい る。

生産管理計画書を作成するために，販売数量の調整 が十分余裕をもって取り組めるようになったため，良 い条件の取り引きが可能になってきた，飼育管理・衛 生管理の計画書を分かりやすく作成して, 鶏舎に示し てあるのでパートも自分の都合を考えた作業計画にな るため, 準備作業の仕事のやりくりがスムーズになっ た.

第 3 に、ネットワークづくりによる経営情報の交換 である. 同年代の意欲ある養鵎経営者や後継者とパッ コンやファクスなどの情報機器を利用して, 自由な情 報交換を目的とした「ラン（卵）ネットワーク」の呼 び掛けを行っている。

最後に, 地域の環境保全への取り組みが挙げられ る. 養鵎場が川支流の水がきれいなところに位置して いるため，環境には特に注意をしている。ニップル领 水器 ${ }^{20)}$ によって排水をなくし, 洗浄水も直接流九込李 ないよらにし，溜め水をして排水している.

高床の鷄舎の鷄䔬についても 3 週間以内に鵎舎から

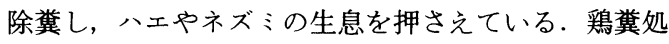
理については, 羽数の増加と共に処理方式を改善し, 現在の鷄䔬処理装置は自動搬送式乾燥機で処理をし，

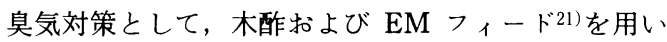

ている.

A経営では，以上みてきたような戦略的経営管理を 行った結果, 経営が改善 (表 4 ) され売り上げが 2.5 倍に増加するよらになった（図1）。これは経営を取 り巻く環境の変化に積極的に対応する明確な経営戦略 の構築と, これに基づいて戦略的経営管理を徹底的に 行った結果であるといえる.

\section{5. むすび一まとめと課題}

本稿では, 今日のような激变する農業経営環境の厳 しい中で, 農業経営が環境要因の変化に対応してどの ような経営戦略を構築していくべきかを，とくに短期 戦略に焦点を当てて明らかにすることを目的にした。 そのための前提として農業経営戦略についての理論的 フレームワークを先行研究を中心にまとめてみた。

そして農業経営を取り巻く農業経営環境要因を外部 環境要因と内部環境要因に分けて整理しながら, 環境 変化に対する農業経営の対応戦略を(1)变換型戦略（組 織変革型), (2)対抗型戦略 (コスト低下型), そして(3) 攻撃型戦略（差別化型）に分類し，その特徵を指摘し た。 また，採卵鵴法人経営を事例として取り上げ，ブ ランド戦略を中心とする農業経営戦略体系の内容と特 徵を整理してみた。この結果, 農業経営が厳しい経営 環境の変化に直面しても自己の経営条件に適応した明 確な経営戦略を構築し, 積極的な戦略的経営管理を行 えば経営成長は可能であることが分かった。

なお，残された課題として自己の経営を取り巻く環 境条件に適応した経営戦略を選択する際の農業経営戦 
略を評価するための評価基準の作成がある，一般企業 経営では戦略代替案の評価基準として，(1)適合性，(2) 妥当性, (3)整合性, (4)実行可能性, (5)脆弱性, (6)潜在 的報酬などを挙げている。この点は農業経営戦略論に おいて今後, 検討すべき重要な課題であろう.

注 1）新山陽子「畜産経営の発展と経営戦略」、農業経営研 究第 34 巻第 2 号, 日本農業経営学会, 1996年, 注 4) を参照.

2）高島健「戦略目標診断における経営計数分析の新視 点」, 日本経営診断学会編『経営診断の理論と技法』, 同友館, 1991年, p.17を参照.

3）佐々木隆「農業経営の展開と経営戦略」、『農業経営研 究第34巻第 2 号, 日本農業経営学会, 1996年, 注 3) を参照.

4）木村伸男『成長農業の経営管理』, 日本経済評論社, 1994年, pp.100〜108，140〜155を参照.

5）大泉一貫『一点突破で元気農業』, 家の光協会, 1993 年, pp.168 189を参照.

6）注 1）の pp.30〜 40を参照.

7) 荒深友良「経営組織と環境」、朝日大学経営論集』第 11 巻第 1 号, 朝日大学経営学会, 1996年, p.231を参 照.

8）日本経営診断学会編『現代経営診断事典』, 同友館, 1994年, pp.122 124を参照.

9）佐々木氏は, 農業を取り巻く变化の内容として, (1)政 策, 制度の变化(輸入自由化, 規制緩和の動き), (2) 情報の変化（情報化の進展による顧客の発見手段の多 様化), (3)物流の変化（流通経路, 流通手段の多様化 ・簡便化), (4)生活スタイルの変化（農業の観光化） などをあげている（注 3）の p . 3）。

10）梅沢昌太郎『農業マーケティング』, 全国農業改良普 及協会, 1997年, pp.30 31を参照.

11）志賀永一「農地市場の動向と経営対応」『日本農業経 営学会研究大会報告要旨』, pp.19 30.

12）注10）の p.35を参照.

13）経営戦略と経営情報との関係を述べてあるものとして は, 小林一「情報を活かしたこれからの農業経営戦
略」『農政調査時報』第 485 号, 全国農業会議所, 1997年。をあげられる.

14）地域農業情報ネットワークの構築に関する文献として は, 農林水産省統計情報部『パンコン等の情報処理技 術を利活用した農業・農村にお战る取組事例』, 1992 年 ; 田口三樹夫他編『地域農業情報システムの構筑』, 農林統計協会, 1993年; 町田武美他『地域農業の情報 戦略 (I)』農林統計協会, 1992年を参照.

15） M.E. ポーター『競争の戦略』, ダイヤモンド社, 1982年, pp.55 71を参照.

16）注 3）の pp.4〜5を参照.

17）八木俊輔「農業経営の㻴境対応関する研究」『農業 経営研究』第29巻第 2 号, 日本農業経営学会, 1991 年, pp.23〜32を参照.

18）ブランド戦略については, 平岡豊『農産物のブランド 作戦』(東洋経済新報社, 1990), 梅沢昌太郎恩藏『農 業のマーケティングと CI 戦略』(全国農業改良普及 協会, 1991), 恩蔵直人『競争優位のブランド戦略』(日 本経済新聞社，1995）などを参照.

19）ブランド卵眅売マニュアルの内容とは，(1) A 養鷄場の 基本, (2)卵の価格・規格・保管・賞味期限等, (3)PL 法, そして(4)ブランド卵の特徵について詳しく説明し ている.

20）鷄舎からの排水の減少, 夏場の軟便防止, 鷄含環境の 改善等を目的として, このタイプの給水器が使われ る. ニップル (nipple) 飲水器は乳首型をした給水器で 鷄がつつくこと（あるいはくわえること）によって所 定の量が出る仕組みになっている. 従来の樋型に比べ

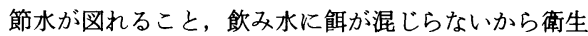
的であるなどが大きな特徵である。

21）環境問題が厳しくなる中で，特に臭気対策として EM 菌を配合した飼料を与えている.EM 菌は微生物とし て光合成菌, 乳酸菌, 放線菌等多数の発醭菌が含まれ ている有用微生物群のことである.畜産的利用では， 直接飼料飞添加する, 畜舎 (鶏舎) の中に散布するも の，翼尿の処理時に添加するなどの利用がある. 利用 目的は, 臭気の低減化, 黛登酵の促進, 堆肥製品の高 品質化等である.

（筆者：岐阜大学） 